\title{
ANALISIS RISIKO KECELAKAAN KERJA METODE HIRA (HAZARD IDENTIFICATION AND RISK ASSESSMENT) DI PT. X
}

\author{
Wita Afnella ${ }^{1}$, Tri Niswati Utami ${ }^{2}$ \\ Fakultas Kesehatan Masyarakat, Universitas Islam Negeri Sumatera Utara \\ afwitaaa@gmail.com ${ }^{1}$, triniswatiutami@uinsu.ac.id ${ }^{2}$
}

\begin{abstract}
The HIRA (Hazard Identification and Risk Assessment) method is a process of identifying hazards that occur in all company activities, then conducting a risk assessment of the hazards that occur. Based on the initial survey conducted at PT. X, it was found that there were work accidents such as pinched hands, cuts, entanglement in processing machines which caused the risk of accidents. This research was conducted at PT. $X$ in February-August 2021. This study used a descriptive qualitative method. This study analyzes the risk of work accidents using the HIRA (Hazard Identification and Risk Assessment) method which aims to identify hazards and conduct a risk assessment of these hazards. The research informants were 6 people consisting of 2 key informants and 4 main informants. Based on the results of hazard identification and risk assessment, there are 54 potential hazards and 44 accident risks spread over 8 stations at PT. X. Based on the results of the study, it was concluded that there were 44 potential hazards and 54 potential risks of accidents spread over 8 work stations at PT. X. The accident category is divided into 7 small risks (trivial), 17 tolerable risks, 15 moderate hazards, 2 substantial hazards, 3 intolerable hazards, which arising from a potential physical hazard.
\end{abstract}

Keywords $\quad$ : Hazard Identification, Risk Analysis, Risk Assessment

\begin{abstract}
ABSTRAK
Metode HIRA (Hazard Identification and Risk assessment) merupakan proses mengidentifikasi bahaya yang terjadi dalam seluruh aktivitas perusahaan, kemudian melakukan penilaian risiko dari bahaya yang terjadi. Berdasarkan survey awal yang telah dilakukan di PT. X ditemui bahwa terdapat kecelakaan kerja seperti tangan terjepit, terpotong, terlilit di mesin pengolahan yang menyebabkan risiko kecelakaan. Penelitian ini dilakukan di PT. X pada bulan Februari-Agustus Tahun 2021. Penelitian ini menggunakan metode kualitatif deskriptif. Penelitian ini menganalisis risiko kecelakaan kerja dengan metode HIRA (Hazard Identification and Risk Assessment) yang bertujuan untuk mengidentifikasi bahaya dan melakukan penilaian risiko terhadap bahaya tersebut. Informan penelitian berjumlah 6 orang yang terdiri atas 2 informan kunci dan 4 informan utama. Berdasarkan hasil identifikasi bahaya dan penilaian risiko terdapat 54 potensi bahaya dan 44 risiko kecelakaan yang tersebar pada 8 stasiun di PT. X. Berdasarkan hasil penelitian diperoleh simpulan bahwa terdapat 44 potensi bahaya dan 54 potensi risiko kecelakaan yang tersebar pada 8 stasiun kerja di PT. $\mathrm{X}$. Kategori kecelakaan tersebut terbagi atas 7 risiko bahaya kecil (trivial), 17 risiko dapat ditoleransi (tolerable), 15 risiko bahaya sedang (moderate), 2 risiko bahaya besar (substantial), 3 risiko bahaya tidak dapat ditoleransi (intolerable), yang timbul akibat adanya potensi bahaya fisik.
\end{abstract}

Kata Kunci $\quad$ : Analisis Risiko, Identifikasi Bahaya, Penilaian Risiko

\section{PENDAHULUAN}

Kecelakaan kerja tidak terjadi secara kebetulan, melainkan ada sebabnya. Ada dua golongan penyebab kecelakaan. Golongan pertama adalah faktor mekanis dan lingkungan, yang meliputi segala sesuatu selain faktor manusia. Golongan kedua adalah manusia itu sendiri yang merupakan penyebab kecelakaan kerja. Penelitian menunjukkan, bahwa $85 \%$ penyebab kecelakaan kerja bersumber dari faktor manusia. Mengenai faktor manusia, sebagai konsekuensinya persoalannya cukup rumit, kecelakaan yang dikarenakan oleh keadaan emosi para pekerja, atau 
berbagai hal unik lainnya yang berkaitan dengan faktor manusia sebagai penyebab kecelakaan (Suma'mur, 2013).

Menurut data

BPJS

Ketenagakerjaam, angka kecelakaan cenderung meningkat dari tahun 2016 hingga 2018. Pada tahun 2016 sebanyak 105.182 kasus kecelakaan kerja, pada tahun 2017 mengalami peningkatan yaitu tercatat ada 123.000 kasus kecelakaan kerja, lalu pada tahun 2018 tercatat sebanyak 173.105 kasus kecelakaan kerja yang dilaporkan. Dari jumlah tersebut sebanyak 4.678 atau $3,18 \%$ diantaranya mengalami cacat dan 2.575 atau $1,75 \%$ lainnya meninggal dunia.(Kementerian Tenaga Kerja, 2018).

Data Badan Pusat Statistik (BPS) pada Agustus 2018, sebanyak 58,76\% dari total angkatan kerja Indonesia adalah tamatan SMP ke bawah. Badan Penyelenggara Jaminan Sosial Ketenagakerjaan Kantor Wilayah Sumatera Utara jumlah kasus kecelakaan kerja sekitar 4.092 kasus yang terjadi di wilayah Aceh dan Sumut dan angka tersebut masih tergolong besar. Hal tersbeut berdampak pada kesadaran pentingnya perilaku selamat dalam bekerja. Daya saing dari sebuah perusahaan juga mempunyai pengaruh terhadap tingkat keselamatan. Menurut Kementrian BUMN dua pertiga dari kasus kecelakaan disebabkan oleh human error (Gati et al., 2020).

Dari hasil wawancara terhadap 8 orang pekerja terdapat 6 orang yang pernah mengalami kecelakaan kerja di PT. $X$. Dapat diketahui bahwa manusia mempunyai peranan yang penting dalam proses produksi kelapa sawit ini. Tugas pekerja tidak hanya sebagai operator pada setiap mesin tetapi juga melakukan pekerjaan manual tanpa bantuan mesin. Berhubungan dengan kinerja manusia dalam menjalankan tugas pada setiap stasiun, sering didapati adanya kesalahankesalahan yang disebabkan karena human error (kesalahan pekerja), tidak memakai sarung tangan, dan lingkungan kerja yang tidak aman. Sehingga pada 5 tahun terakhir terdapat kecelakaan kerja seperti tangan terjepit di tali penggerak, kaki masuk ke air panas karena terpleset, tangan terpotong tali penggerak, dan jempol kaki terpotong mesin penggilingan.

Keselamatan dan Kesehatan kerja merupakan hal yang sangat penting diterapkan di setiap institusi baik milik pemerintah maupun swasta termasuk diantaranya adalah pabrik kelapa sawit. Berdasarkan hasil pengamatan awal diatas, upaya untuk dapat meminimalisir kecelakaan kerja yang terjadi maka perusahaan harus melakukan pengendalian terhadap risiko kecelakaan kerja yang ada. Untuk membantu dalam penyelesaian masalah tersebut penelitian ini menggunakan metode HIRA yang bertujuan untuk memetakan potensi bahaya yang terjadi pada setiap proses kerja. Sehingga mampu mengidentifikasi dan menilai risiko terhadap kecelakaan.

Penelitian ini sejalan dengan penelitian sebelumnya oleh Rehuel (2020) Identifikasi Bahaya, Penilaian Risiko, dan Pengendalian Risiko Menggunakan Analisis Metode HIRA, oleh Taofiq (2019), Analisis penilaian risiko dan kejadian kecelakaan kerja di Pabrik Pengolahan Kelapa Sawit, oleh Aditya (2018) Manajemen risiko K3 menggunakan HIRA, oleh Ramdan dkk (2017), oleh (Alfatiyah, 2017) Identifikasi bahaya dan penilaian risiko pada Divisi Boiler menggunakan metode HIRARC dan Analisis manajemen risiko $\mathrm{K} 3$ dengan menggunakan metode HIRARC. Tujuan dari penelitian ini adalah melakukan identifikasi bahaya, menilai risiko bahaya menggunakan analisis metode HIRA agar tidak terjadi kecelakaan kerja yang membahayakan pekerja dan melindungi pekerja dari bahaya yang terjadi di perusahaan.

\section{METODE}

Penelitian dilakukan dengan pendekatan deskriptif kualitatif. Penelitian 
dilaksanakan di Pabrik pengolahan kelapa sawit PT. X Kabupaten Simalungun. Waktu yang dibutuhkan untuk melaksanakan penelitian ini yakni selama tujuh bulan, mulai dari bulan Februari sampai dengan Agustus 2021. Informan dalam penelitian ini berjumlah 6 orang yang terdiri dari informan kunci 2 orang (Manager, Asisten Pengolahan), dan informan utama 4 orang pekerja. Penelitian ini menganalisis risiko kecelakaan kerja dengan menggunakan metode HIRA merupakan proses mengidentifikasi bahaya yang terjadi dalam seluruh aktivitas perusahaan, kemudian melakukan penilaian risiko dari bahaya yang terjadi (Rehuel, 2020).
Analisis risiko pekerjaan dapat dilihat melalui 2 hal, yaitu kemungkingkan (probability) dan keparahan (severity) (ILO, 2018). Proses penilaian tersebut antara lain, yaitu tingkat kemungkinan (probability). Tingkat kemungkinan terjadinya kecelakaan atau sakit akibat kerja, harus mempertimbangkan tentang seberapa sering dan berapa lama seorang tenaga kerja terpapar potensi bahaya. Dengan demikian dapat dibuat keputusan tentang tingkat kekerapan kecelakaan untuk setiap potensi bahaya yang diidentifikasi. Kategori tingkat kemungkinan terjadinya risiko dapat dilihat pada tabel 1 .

\section{Tabel 1. Tingkat Kemungkinan (Probability) pada Standar ILO : 2018}

\begin{tabular}{llc}
\hline \multicolumn{3}{c}{ Karakterisasi dan Skala Kemungkinan Kerusakan } \\
\hline Tingkat kualitatif & \multicolumn{1}{c}{ Karakterisasi } & Nilai \\
\hline Low/ Rendah & Diperkirakan itu mungkin jarang terjadi & 1 \\
Average/ Rata-rata & Diperkirakan terjadi dengan relatif mudah & 3 \\
High/Tinggi & Diperkirakan akan sering terjadi & 6 \\
\hline
\end{tabular}

Sumber: (ILO, 2018)

Selanjutnya tingkat keparahan (severity). Penentuan tingkat keparahan dari suatu kecelakaan juga memerlukan pertimbangan tentang berapa banyak orang yang ikut terkena dampak akibat kecelakaan dan bagian-bagian tubuh mana saja yang dapat terpapar potensi bahaya. Kategori tingkat keparahan dapat dilihat pada tabel 2.

Tabel 2. Tingkat Keparahan (Severity) pada Standar (ILO : 2018)

\begin{tabular}{lcc}
\hline \multicolumn{1}{c}{ Karakterisasi dan Skala Kepaarahan Kerusakan } & \multicolumn{1}{c}{ Karakterisasi } & Nilai \\
\hline \multicolumn{1}{c}{ Tingkat kualitatif } \\
$\begin{array}{l}\text { Sedikhtly Harmful/ } \\
\text { Harmful/ Berbahaya }\end{array}$ & Luka kecil, iritasi mata, sakit kepala, ketidaknyamanan & 1 \\
& $\begin{array}{l}\text { Laserasi, luka bakar, patah tulang ringan, tuli, penyakit } \\
\text { kulit, asma, gangguan musculoskeletal }\end{array}$ & 3 \\
$\begin{array}{l}\text { Extremely Harmful/ } \\
\text { Sangat berbahaya }\end{array}$ & $\begin{array}{l}\text { Amputasi, patah tulang besar, keracunan, lesimultipel, } \\
\text { kanker, penyakit kronis, kematian. }\end{array}$ & 6 \\
\hline
\end{tabular}

Sumber: (ILO, 2018)

Tabel 3. Matriks Penilaian Risiko pada Standar (ILO : 2018)

\begin{tabular}{cccc}
\hline \multirow{2}{*}{ Probability } & \multicolumn{3}{c}{ Severity } \\
\cline { 2 - 4 } & Slightly Harmful & Harmful & Extremely Harmful \\
\hline Low & Trivial & Tolerable & Moderate \\
Average & Tolerable & Moderate & Substantial \\
High & Moderate & Substantial & Intolerable \\
\hline
\end{tabular}

Sumber: (ILO, 2018) 
Tabel 4. Skala Ukur Tingkat Risiko pada Standar (ILO : 2018)

\begin{tabular}{|c|c|}
\hline Risk level & Preventive and protective measures \\
\hline $\begin{array}{l}\text { Trivial/ risiko } \\
\text { kecil }\end{array}$ & Tidak memerlukan tindakan khusus \\
\hline $\begin{array}{l}\text { Tolerablel } \\
\text { risiko dapat } \\
\text { ditoleransi }\end{array}$ & $\begin{array}{l}\text { Tidak perlu meningkatkan tindakan pencegahan. Namun, membutuhkan solusi } \\
\text { atau perbaikan yang lebih hemat biaya yang tidak menimbulkan beban ekonomi } \\
\text { yang signifikan sehingga harus dipertimbangkan. Pemeriksaan rutin diperlukan } \\
\text { untuk memastikan bahwa efektivitas tindakan pengendalian dipertahankan. }\end{array}$ \\
\hline $\begin{array}{l}\text { Moderatel } \\
\text { risiko sedang }\end{array}$ & $\begin{array}{l}\text { Harus dilakukan upaya untuk mengurangi risiko. Langkah-langkah untuk } \\
\text { mengurangi risiko harus diambil dalam jangka waktu tertentu. Dimana risiko } \\
\text { dikaitkan dengan konsekuensi yang sangat merusak, tindakan lebih lanjut akan } \\
\text { diperlukan untuk menetapkan lebih tepat kemungkinan kerusakan sebagai dasar } \\
\text { untuk menentukan kebutuhan untuk meningkatkan tindakan pengendalian. }\end{array}$ \\
\hline $\begin{array}{l}\text { Substantial/ } \\
\text { risiko besar }\end{array}$ & $\begin{array}{l}\text { Pekerjaan tidak boleh dimulai sampai risiko telah berkurang. Diperlukan } \\
\text { sumber daya yang cukup besar untuk pengendalian risiko. Ketika risiko sesuai } \\
\text { dengan pekerjaan yang sedang dilakukan, langkah yang harus diambil adalah } \\
\text { mengurangi tingkat risiko, sesegera mungkin dan dalam waktu yang lebih } \\
\text { singkat dari pada kasus risiko sedang. }\end{array}$ \\
\hline $\begin{array}{l}\text { Intolerablel } \\
\text { risiko tidak } \\
\text { dapat } \\
\text { ditoleransi }\end{array}$ & $\begin{array}{l}\text { Tidak boleh memulai atau melanjutkan pekerjaan sampai risiko berkurang. } \\
\text { Bahkan jika menggunakan sumber daya yang tidak terbatas, pekerjaan tersebut } \\
\text { harus dilarang sampai tingkat risiko telah dikurangi ke tingkat yang dapat } \\
\text { diterima. }\end{array}$ \\
\hline
\end{tabular}

HASIL

Pada PT. X dalam mengolah tandan buah sawit (TBS) menjadi crude palm oil (CPO) dan Palm Kernel dilakukan dengan beberapa tahapan yang dimulai dengan stasiun sortasi, loading ramp, sterilizer/rebusan, press, klarifikasi, nut dan kernel, boiler, dan engine room.
Selama proses pengolahan beroperasi dengan menggunakan mesin, kecuali pada stasiun sortasi. Berdasarkan hasil observasi dan wawancanra diperoleh identifikasi bahaya/hazard identification pada PT. X tersaji pada tabel 5. Dan hasil dari penilaian risiko/risk assessment pada PT. $\mathrm{X}$ tersaji pada tabel 6 .

\section{Tabel 5. Hazard Identification}

\begin{tabular}{|c|c|c|}
\hline \multicolumn{3}{|l|}{ Stasiun sortasi } \\
\hline Activity & Hazard & Risk \\
\hline $\begin{array}{l}\text { Mengarahkan truk ke lokasi } \\
\text { pembongkaran }\end{array}$ & Tertabrak truk & Cidera/ kematian \\
\hline $\begin{array}{l}\text { Pekerja melepas jaring tandan buah } \\
\text { segar(TBS) }\end{array}$ & $\begin{array}{l}\text { Terjatuh dari atas truk saat membuka } \\
\text { jarring }\end{array}$ & $\begin{array}{l}\text { Cidera } \\
\text { Luka }\end{array}$ \\
\hline $\begin{array}{l}\text { Pembongkaran TBS manual } \\
\text { menggunakan tojok/gancu }\end{array}$ & $\begin{array}{l}\text { Jari tangan terjepit tali } \\
\text { Tertusuk tojok/gancu } \\
\text { Tertimpa TBS } \\
\text { Tertusuk duri TBS } \\
\text { Terpleset/terjatuh }\end{array}$ & $\begin{array}{l}\text { Luka } \\
\text { Cidera } \\
\text { Luka } \\
\text { Cidera }\end{array}$ \\
\hline \multicolumn{3}{|l|}{ Stasiun loading ramp } \\
\hline $\begin{array}{l}\text { Mengoperasikan hidrolik untuk } \\
\text { membuka pintu loading ramp dan } \\
\text { menyusun TBS agar lori terisi penuh }\end{array}$ & $\begin{array}{l}\text { Terpleset/terjatuh saat menaiki/ } \\
\text { menuruni tangga loading ramp } \\
\text { Tersetrum listrik }\end{array}$ & $\begin{array}{l}\text { Cidera } \\
\text { Luka } \\
\text { kematian } \\
\text { Cidera }\end{array}$ \\
\hline $\begin{array}{l}\text { Pekerja memasukkan TBS yang jatuh } \\
\text { keluar }\end{array}$ & Tertimpa TBS & Cidera \\
\hline
\end{tabular}




\begin{tabular}{|c|c|c|}
\hline $\begin{array}{l}\text { Pekerja menarik tali (sling) capstand } \\
\text { menuju transfer carriage dan strelizer }\end{array}$ & $\begin{array}{l}\text { Terpleset/ terjatuh } \\
\text { Tertusuk sling }\end{array}$ & $\begin{array}{l}\text { Cidera } \\
\text { Luka }\end{array}$ \\
\hline Mengoperasikan mesin capstand & $\begin{array}{l}\text { Tersetrum panel listrik } \\
\text { Terkena sling putus dan V-belt } \\
\text { capstand }\end{array}$ & $\begin{array}{l}\text { Luka bakar/ } \\
\text { kematian } \\
\text { Cidera } \\
\text { Terjepit/ terpotong }\end{array}$ \\
\hline Mengoperasikan transfer carriage & $\begin{array}{l}\text { Tertimpa lori yang anjlok } \\
\text { Tersetrum listrik } \\
\text { Terjepit antara lori saat melepas rantai } \\
\text { penyambung antar lori }\end{array}$ & $\begin{array}{l}\text { Cidera/ kematian } \\
\text { Luka bakar/ } \\
\text { kematian } \\
\text { Luka/cidera/ } \\
\text { amputasi }\end{array}$ \\
\hline Stasiun rebusan/ sterilizer & & \\
\hline $\begin{array}{l}\text { Mengoperasikan control room } \\
\text { sterilizer }\end{array}$ & $\begin{array}{l}\text { Tersetrum listrik } \\
\text { Peledakan sterilizer }\end{array}$ & $\begin{array}{l}\text { Luka bakar/ } \\
\text { kematian } \\
\text { Cidera/ kematian } \\
\end{array}$ \\
\hline Membuka atau menutup pintu rebusan & $\begin{array}{l}\text { Terjepit pintu rebusan } \\
\text { Tersembur uap panas }\end{array}$ & $\begin{array}{l}\text { Luka/ amputasi } \\
\text { Luka bakar }\end{array}$ \\
\hline $\begin{array}{l}\text { Mendorong/menggeser jalur } \\
\text { penyambung rel lori untuk } \\
\text { memasukkan lori ke tabung sterilizer }\end{array}$ & $\begin{array}{l}\text { Tergelincir } \\
\text { Manual handling }\end{array}$ & $\begin{array}{l}\text { Luka pada tubuh } \\
\text { Keseleo/ dislokasi }\end{array}$ \\
\hline $\begin{array}{l}\text { Pekerja menarik tali (sling) capstand } \\
\text { menuju transfer carriage dan strelizer }\end{array}$ & $\begin{array}{l}\text { Terpleset/terjatuh } \\
\text { Tertusuk sling }\end{array}$ & $\begin{array}{l}\text { Cidera } \\
\text { Luka }\end{array}$ \\
\hline Mengoperasikan mesin capstand & $\begin{array}{l}\text { Tersetrum listrik } \\
\text { Terkena sling putus atau V-belt } \\
\text { capstand }\end{array}$ & $\begin{array}{l}\text { Luka } \\
\text { kematian } \\
\text { Cidera } \\
\text { Terjepit }\end{array}$ \\
\hline Mengoperasikan transfer carriage & $\begin{array}{l}\text { Tertimpa lori yang anjlok } \\
\text { Tersetrum listrik } \\
\text { Terkena TBS panas }\end{array}$ & $\begin{array}{l}\text { Cidera/ kematian } \\
\text { Luka bakar/ } \\
\text { kematian } \\
\text { Luka bakar }\end{array}$ \\
\hline \multicolumn{3}{|l|}{ Stasiun press } \\
\hline $\begin{array}{l}\text { Mengoperasikan mesin digester dan } \\
\text { press }\end{array}$ & $\begin{array}{l}\text { Terjatuh saat menaiki/ menuruni } \\
\text { tangga } \\
\text { Tersetrum listrik } \\
\text { Cipratan minyak panas }\end{array}$ & $\begin{array}{l}\text { Cidera } \\
\text { Luka bakar/ } \\
\text { kematian } \\
\text { Luka bakar }\end{array}$ \\
\hline Membersihkan area kerja & Terpleset lantai licin & $\begin{array}{l}\text { Cidera/luka } \\
\text { Luka bakar }\end{array}$ \\
\hline \multicolumn{3}{|l|}{ Stasiun klarifikasi } \\
\hline $\begin{array}{l}\text { Mengoperasikan semua mesin } \\
\text { (vibrating screan, tank, clarifier tank, } \\
\text { sludge tank and pump, dan pure oil } \\
\text { pum) }\end{array}$ & $\begin{array}{l}\text { Terpleset tangga licin } \\
\text { Cipratan minyak panas } \\
\text { Tersetrum listrik } \\
\text { Terjepit V-belt chain coupling }\end{array}$ & $\begin{array}{l}\text { Cidera/luka } \\
\text { Luka bakar } \\
\text { Luka bakar/ } \\
\text { kematian } \\
\text { Cidera/luka } \\
\end{array}$ \\
\hline Membersihkan area kerja & Terpleset lantai licin & $\begin{array}{l}\text { Cidera/luka } \\
\text { Luka bakar }\end{array}$ \\
\hline \multicolumn{3}{|l|}{ Stasiun nut dan kernel } \\
\hline $\begin{array}{l}\text { Mengoperasikan semua mesin (nut } \\
\text { polishing drum, nut conveyor, kernel } \\
\text { elevator, bulking silo dan ripple mill) }\end{array}$ & $\begin{array}{l}\text { Terpleset tangga } \\
\text { Terjepit } V \text {-belt chain coupling } \\
\text { Terpapar } \text { nut polishing drum }\end{array}$ & $\begin{array}{l}\text { Cidera/luka } \\
\text { Cidera/luka } \\
\text { Cidera/luka }\end{array}$ \\
\hline $\begin{array}{l}\text { Membersihkan area kerja } \\
\text { Stasiun boiler }\end{array}$ & Terpleset lantai licin & Cidera/luka \\
\hline $\begin{array}{l}\text { Mengoperasikan semua mesin (boiler, } \\
\text { conveyor/van, dan fire up) }\end{array}$ & $\begin{array}{l}\text { Terpleset tangga } \\
\text { Tersembur abu/api pembakaran } \\
\text { Terpapar uap minyak } \\
\text { Tersetrum listrik } \\
\text { Peledakan boiler }\end{array}$ & $\begin{array}{ll}\text { Cidera/luka } & \\
\text { Luka bakar } & \\
\text { Luka bakar } & \\
\text { Luka } & \text { bakar/ } \\
\text { kematian } & \\
\text { Cidera/luka } & \text { bakar/ } \\
\text { kematian } & \end{array}$ \\
\hline
\end{tabular}




\begin{tabular}{llc}
\hline Engine room & & \\
\hline Mengoperasikan semua mesin (genset, & Peledakan turbin & \\
turbin, dan control pendistribusian & Peledakan genset & Cidera/luka \\
listrik) & Tersetrum listrik & bakar/kematian \\
& & Terkena uap minyak
\end{tabular}

Tabel 6. Risk Assessment

\begin{tabular}{|c|c|c|c|c|c|c|c|c|c|c|c|c|}
\hline \multicolumn{13}{|c|}{ Stasiun sortasi } \\
\hline & \multirow{2}{*}{ Hazard } & \multicolumn{3}{|c|}{ Probability } & \multicolumn{3}{|c|}{ Severity } & \multicolumn{5}{|c|}{ Risk Estimation } \\
\hline & & $\mathbf{L}$ & $\mathbf{A}$ & HI & SH & $\mathbf{H}$ & EH & $\mathbf{T}$ & $\mathbf{O}$ & $\mathbf{M}$ & $\mathbf{S}$ & $\mathbf{I}$ \\
\hline 1 & Tertabrak truk & $\mathrm{L}$ & & & & $\mathrm{H}$ & & & & & & \\
\hline 2 & $\begin{array}{l}\text { Terjatuh dari atas truk } \\
\text { saat membuka jarring }\end{array}$ & $\mathrm{L}$ & & & $\mathrm{SH}$ & & & & & & & \\
\hline 3 & Jari tangan terjepit tali & $\mathrm{L}$ & & & $\mathrm{SH}$ & & & & & & & \\
\hline 4 & Tertusuk tojok/gancu & & A & & $\mathrm{SH}$ & & & & & & & \\
\hline 5 & Tertimpa TBS & & & $\mathrm{HI}$ & $\mathrm{SH}$ & & & & & & & \\
\hline 6 & Tertusuk duri TBS & & A & & $\mathrm{SH}$ & & & & & & & \\
\hline 7 & Terpleset/terjatuh & $\mathrm{L}$ & & & $\mathrm{SH}$ & & & & & & & \\
\hline \multicolumn{13}{|c|}{ Stasiun loading ramp } \\
\hline 1 & $\begin{array}{l}\text { Terpleset saat menaiki/ } \\
\text { menuruni tangga }\end{array}$ & & A & & $\mathrm{SH}$ & & & & & & & \\
\hline 2 & Tersetrum listrik & $\mathrm{L}$ & & & & $\mathrm{H}$ & & & & & & \\
\hline 3 & Tertimpa TBS & & A & & $\mathrm{SH}$ & & & & & & & \\
\hline 4 & Tertusuk sling & & & $\mathrm{HI}$ & & $\mathrm{H}$ & & & & & & \\
\hline 5 & $\begin{array}{l}\text { Terkena v-belt } \\
\text { capstand }\end{array}$ & & & $\mathrm{HI}$ & & & $\mathrm{EH}$ & & & & & \\
\hline 6 & $\begin{array}{l}\text { Tertimpa lori yang } \\
\text { anjlok }\end{array}$ & & A & & & $\mathrm{H}$ & & & & & & \\
\hline 7 & $\begin{array}{l}\text { Terjepit antara lori saat } \\
\text { melepas rantai } \\
\text { penyambung antar lori }\end{array}$ & & & $\mathrm{HI}$ & & & $\mathrm{EH}$ & & & & & \\
\hline \multicolumn{13}{|c|}{ Stasiun rebusan/ sterilizer } \\
\hline 1 & Tersetrum listrik & $\mathrm{L}$ & & & & $\mathrm{H}$ & & & & & & \\
\hline 2 & Peledakan sterilizer & $\mathrm{L}$ & & & & $\mathrm{H}$ & & & & & & \\
\hline 3 & Terjepit pintu rebusan & $\mathrm{L}$ & & & $\mathrm{SH}$ & & & & & & & \\
\hline 4 & Tersembur uap panas & & A & & & $\mathrm{H}$ & & & & & & \\
\hline 5 & Tergelincir & & A & & & $\mathrm{H}$ & & & & & & \\
\hline 6 & Manual handling & $\mathrm{L}$ & & & $\mathrm{SH}$ & & & & & & & \\
\hline 7 & $\begin{array}{l}\text { Terkena sling putus/ } \\
\text { V-belt capstand }\end{array}$ & & A & & & $\mathrm{H}$ & & & & & & \\
\hline 8 & $\begin{array}{l}\text { Tertimpa lori yang } \\
\text { anjlok }\end{array}$ & & A & & & & $\mathrm{EH}$ & & & & & \\
\hline 9 & Terkena TBS panas & $\mathrm{L}$ & & & $\mathrm{SH}$ & & & & & & & \\
\hline \multicolumn{13}{|c|}{ Stasiun press } \\
\hline 1 & $\begin{array}{l}\text { Terjatuh saat menaiki/ } \\
\text { menuruni tangga }\end{array}$ & $\mathrm{L}$ & & & & $\mathrm{H}$ & & & & & & \\
\hline 2 & Tersetrum listrik & $\mathrm{L}$ & & & & $\mathrm{H}$ & & & & & & \\
\hline 3 & Cipratan minyak panas & & A & & & $\mathrm{H}$ & & & & & & \\
\hline 4 & Terpleset lantai licin & & A & & & $\mathrm{H}$ & & & & & & \\
\hline \multicolumn{13}{|c|}{ Stasiun klarifikasi } \\
\hline 1 & Terpleset tangga licin & & A & & $\mathrm{SH}$ & & & & & & & \\
\hline 2 & Cipratan minyak panas & & A & & & $\mathrm{H}$ & & & & & & \\
\hline 3 & Tersetrum listrik & $\mathrm{L}$ & & & & $\mathrm{H}$ & & & & & & \\
\hline 4 & $\begin{array}{l}\text { Terjepit } V \text {-sbelt chain } \\
\text { coupling }\end{array}$ & & & $\mathrm{HI}$ & & & $\mathrm{EH}$ & & & & & \\
\hline 5 & $\begin{array}{l}\text { Tersembur uap parit } \\
\text { pembuangan sisa } \\
\text { pemurnian minyak }\end{array}$ & $\mathrm{L}$ & & & & $\mathrm{H}$ & & & & & & \\
\hline
\end{tabular}




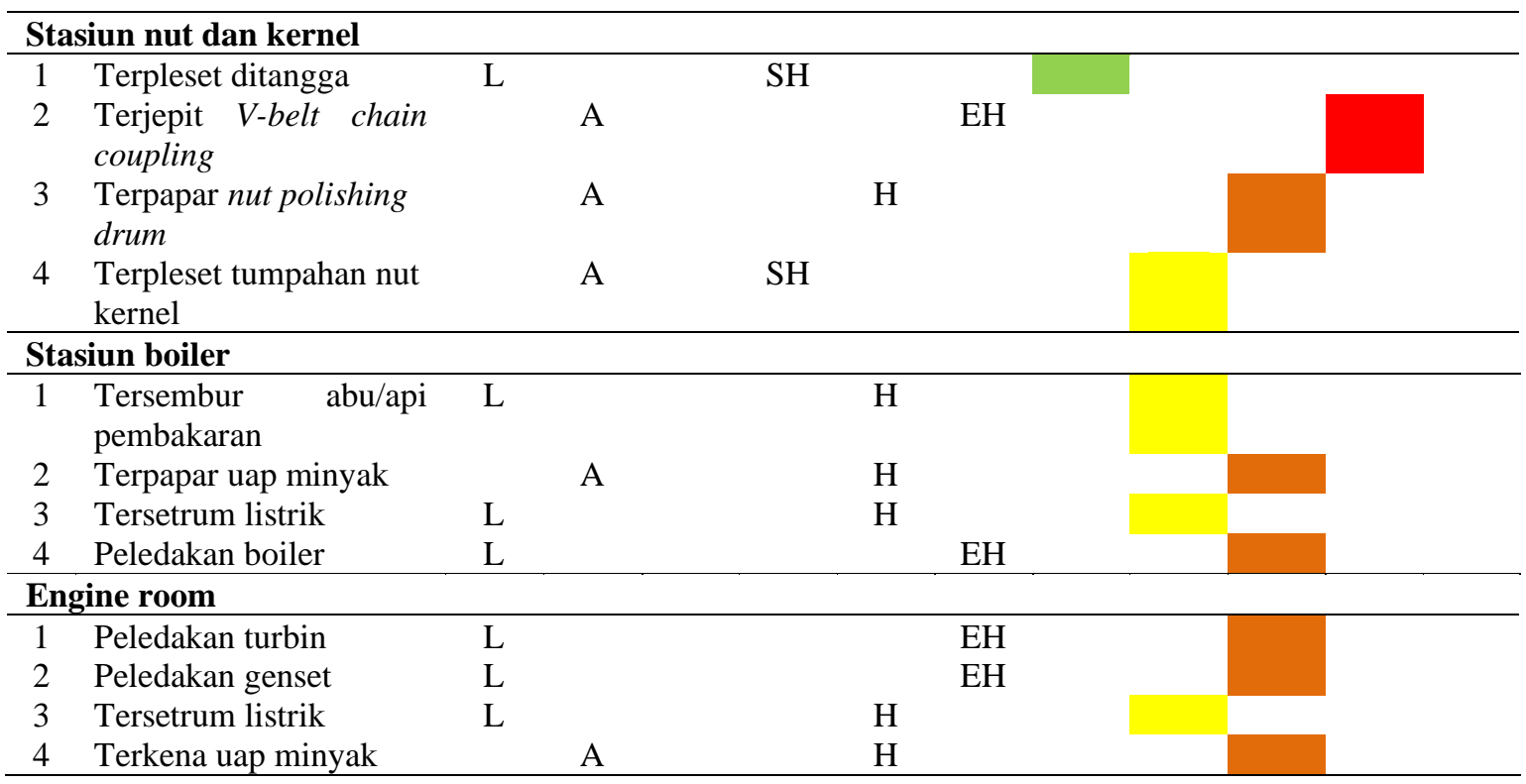

Keterangan: L; Low, A; Average, H; High, SH; Slightly Harmful, H; Harmful, EH; Extremely

Harmful, T; Trivial, O; Tolerable, M; Moderate, S; Substantial, I; Intolerable.

\section{PEMBAHASAN}

Di tempat kerja terdapat sumber bahaya yang beraneka ragam diantaranya bahaya fisik, bahaya ergonomi, bahaya kimia, bahaya biologi, dan bahaya psikologi. Hazard juga dapat dibagi menjadi 3 kategori, yaitu bahaya kesehatan, bahaya kecelakaan, dan bahaya lingkungan (Halim \& Panjaitan, 2016). Jenis bahaya dalam penelitian ini adalah bahaya fisik yang telah diidentifikasi dari risiko keselamatan kerja yang terdapat pada setiap stasiun kerja.

Hasil rata-rata penilaian risiko/risk assessment menunjukkan bahwa area pengolahan kelapa sawit di PT. X berada pada level yang berisiko. Dapat dilihat pada tabel 6 bahwa dari 44 risiko kecelakaan terbagi atas 7 risiko bahaya kecil (trivial), 17 risiko dapat ditoleransi (tolerable), 15 risiko bahaya sedang (moderate), 2 risiko bahaya besar (substantial), 3 risiko bahaya tidak dapat ditoleransi (intolerable).

Pada tingkat risiko tidak dapat ditoleransi (intolerable) dan tingkat risiko besar (substantial) ditemukan pada bahaya terkena $v$-belt capstand dan terjepit antar lori saat melepas rantai penyambung lori.
Temuan penelitian ini didukung dari hasil observasi dan wawancara kepada pekerja di PT. $X$ yang pernah mengalami kecelakaan yaitu tangan terpotong akibat terjepit di v-belt chains coupling, v-belt capstand dan rantai penyambung lori yang termasuk ke dalam risiko bahaya besar (substaintial) dan risiko bahaya tidak dapat ditoleransi (intolerable).

Hasil penelitian ini di dukung oleh penelitian sebelumnya oleh (Jonathan, 2017) menggambarkan stasiun perebusan terdapat potensi bahaya keselamatan yaitu terjatuh, terbentur, tersembur uap panas, tertusuk tali capstand dan terpleset saat pekerja menarik tali capstand.

Penelitian ini juga sejalan dengan penelitian (Asrina, 2017) bahwa pada stasiun loading ramp pekerja rentan terpleset pada saat menarik tali capstand yang diakibatkan lantai licin karena banyak oli di sekitar wilayah kerja dan memiliki potensi melukai tangan pekerja apabila tidak dilakukan penggantian dan perawatan secara rutin pada tali capstand.

Berdasarkan hasil penilaian risiko, upaya pengendalaian yang digunakan risiko bahaya besar (substaintial) dan risiko bahaya tidak dapat ditoleransi (intolerable) pada penelitian ini adalah 
hirarki pengendalian K3 mulai dari eliminasi, substitusi, pengendalian teknik, administrasi dan alat pelindung diri.

Upaya pengendalian yang dapat dilakukan adalah membersihkan tangga dan menambah rambu bahaya, mendesain barrier atau penutup $v$-belt, mengecek kondisi dan keadaan mesin-mesin di setiap stasiun kerja, melakukan pekerjaan sesuai SOP serta penggunaan alat pelindung diri.

Hasil penelitian ini sejalan dengan (Amni, 2021) bahwa pengendalian yang dilakukan pada pekerjaan yang memiliki tingkat extreme risk pada stasiun loading ramp yaitu mewajibkan penggunaan APD (Alat Pelindung Diri) bagi para pekerja, mengganti dan melakukan perawatan pada tali capstand serta membersihkan lantai produksi secara rutin.

Selanjutnya masih dalam penelitian (Amni, 2021) pengendalian yang dilakukan pada tingkat high risk dan extreme risk pada stasiun rebusan yaitu mewajibkan pekerja menggunakan APD, mengganti dan merawat tali capstand, memperhatikan dan memastikan kondisi mesin dalamm tekanan suhu normal sebelum melakukan perbaikan pada lori yang berada di dalam mesin perebusan, dan menggunakan mesin pengangkat lori ketika lori jatuh dari sangggahan.

\section{KESIMPULAN}

Berdasarkan hasil penelitian diperoleh simpulan bahwa terdapat 44 potensi bahaya dan 54 potensi risiko kecelakaan yang tersebar pada 8 stasiun kerja di PT. $\mathrm{X}$. Kategori kecelakaan tersebut terbagi atas 7 risiko bahaya kecil (trivial), 17 risiko dapat ditoleransi (tolerable), 15 risiko bahaya sedang (moderate), 2 risiko bahaya besar (substantial), 3 risiko bahaya tidak dapat ditoleransi (intolerable), yang timbul akibat adanya potensi bahaya fisik. Hasil rekomendasi yang dapat diberikan yaitu berdasarkan hirarki pengendalian K3 meliputi, rekayasa teknik, administrasi dan APD. Mengenai penelitian lanjutan sebaiknya tentang desain budaya K3 yang sesuai untuk dapat diterapkan di PT. X.

\section{UCAPAN TERIMAKASIH}

Peneliti mengucapkan terima kasih kepada Allah subhanahu wata'ala, orang tua, dosen pembimbing dibidang kesehatan masyarakat dan teman seperjuangan. Semoga Allah selalu memberikan keberkahan.

\section{DAFTAR PUSTAKA}

Amni, R. (2021). Analisa Potensi Bahaya dengan Menggunakan Metode HIRA. Seminar dan Konferensi Nasional IDEC.

Alfatiyah, R. (2017). Analisis Manajemen Risiko Keselamatan dan Kesehatan Kerja dengan Menggunakan Metode HIRARC pada Pekerja Seksi Casting. Jurnal Mesin Teknologi (SINTEK Jurnal), 11(2), 88-101.

Gati, M. W., Wahyuni, I., \& Ekawati, E. (2020). Analisis Penyebab Human Error Terhadap Kejadian Kecelakaan Pada Teknisi Di Perusahaan Otomotif X, Semarang. Jurnal Kesehatan Masyarakat ..., 8(September), 665-671.

Halim, L. N., \& Panjaitan, T. W. S. (2016). Perancangan Dokumen Hazard Identification Risk Assessment Risk Control (HIRARC) Pada Perusahaan Furniture: Studi Kasus. Jurnal Titra, 4(2), 279-284.

ILO. (2018). Occupational Risk Management And Occupational Safety And Health Management Systems. In European Agency for Safety and Health at Work (Nomor 465).

Jonathan. (2017). Analisis Bahaya Keselamatan Pada Pekerja Bagian Produksi Pabrik Minyak Kelapa Sawit PT PP London Sumatra Tbk Tanjung Morawa. Skripsi Program Studi Kesehatan Masyarakat.

Kementerian Tenaga Kerja. (2018). Peraturan Menteri Tenaga Kerja No 5/2018 K3 Lingkungan Kerja. Permenakertrans, 5, $1-258$.

https://jdih.kemnaker.go.id/keselamatan 
-kerja.html

Rehuel, Y. (2020). Identifikasi Bahaya, Penilaian Risiko, dan Pengendalian Risiko Menggunakan Analisis Metode HIRARC. Jurnal Penelitian Perawat Profesional, 1(November), 89-94. http://jurnal.globalhealthsciencegroup.c om/index.php/JPPP/article/download/83 165

Suma'mur. (2013). Keselamatan Kerja dan Pencegahan Kecelakaan. CV Haji Masagung. 